\title{
Nilai Transaksi Non Tunai Terhadap Pertumbuhan Ekonomi Di Indonesia Periode 2014-2018
}

\author{
Ratnawaty Marginingsih, Imelda Sari \\ Universitas Bina Saran Informatika, Indonesia \\ ratnawaty.rmg@bsi.ac.id
}

\begin{abstract}
This research was conducted aiming to be able to see the effect of non-cash payment instruments on economic growth in Indonesia in the latest period. The study focused on noncash transaction variables including data on the use of debit / ATM cards. credit card and emoney. to determine its effect on economic growth in Indonesia with an indicator of the value of Gross Domestic Product (GDP) in the period 2014-2018. This study uses quantitative descriptive methods using secondary data in the form of monthly reports on the value of debit I ATM card transactions, credit cards, and e-money issued by Bank Indonesia (BI) and the value of Gross Domestic Product (GDP) published by the Central Statistics Agency (BPS). The results of this study found that the overall independent variables used simultaneously affect the economic growth with Gross Domestic Product (GDP) indicators. Partially the use of debit cards/ATMs, credit cards and e-money have a significant positive effect on economic growth in Indonesia.
\end{abstract}

Keywords: Non-Cash Transactions, Debit /ATM Cards, Credit Cards, E-Money, Economic Growth

\begin{abstract}
ABSTRAK
Penelitian ini dilakukan bertujuan untuk dapat melihat pengaruh alat pembayaran non tunai terhadap pertumbuhan ekonomi di Indonesia pada periode terbaru. Penelitian di fokuskan pada variabel transaksi non tunai meliputi data penggunaan kartu debit/ATM. kartu kredit dan e-money. untuk mengetahui pengaruhnya terhadap pertumbuhan ekonomi di Indonesia dengan indikator nilai Produk Domestik Bruto (PDB) pada periode tahun 2014-2018. Penelitian ini menggunakan metode deskriptif kuantitatif dengan menggunakan data sekunder berupa laporan bulanan nilai transaksi kartu debet/ATM, kartu kredit, dan e-money yang diterbitkan oleh Bank Indonesia (BI) dan nilai Produk Domestik Bruto (PDB) yang diterbitkan oleh Badan Pusat Statistik (BPS). Hasil penelitian ini ditemukan bahwa keseluruhan variabel independen yang digunakan berpengaruh secara simultan terhadap Pertumbuhan ekonomi dengan indikator Produk Domestik Bruto (PDB). Secara parsial penggunaan kartu debet/ATM, Kartu kredit dan e-money berpengaruh positif signifikan terhadap Pertumbuhan ekonomi di Indonesia.
\end{abstract}

Kata Kunci : Transaksi Non Tunai, Kartu Debet/ATM, Kartu Kredit, E-Money, Pertumbuhan Ekonomi 


\section{Pendahuluan}

Pesatnya perkembangan teknologi informasi telah merambah ke berbagai sektor kehidupan. Segala kebutuhan masyarakat semakin dipermudah dengan layanan sistem pembayaran elektronik atau pembayaran non tunai. Pembayaran non tunai semakin menjadi tren masyarakat Indonesia baik di perkotaan maupun perdesaan. Uang non tunai dinilai lebih efektif sebagai alat transaksi pembayaran dan menjadi penggerak utama pertumbuhan ekonomi saat ini. Bank Indonesia (BI) mencatat, nilai transaksi uang elektronik naik dua kali lipat menjadi Rp31,66 triliun sepanjang Januari hingga September 2018 dibandingkan sepanjang 2017. Penggerak utama pertumbuhan non tunai tersebut antara lain berasal dari pembayaran online dan uang elektronik.

Perubahan daya beli masyarakat terjadi karena adanya pergeseran pola belanja masyarakat dari perdagangan konvensional menjadi perdagangan elektronik. Semakin kompleksnya kegiatan perekonomian masyarakat menuntut tersedianya sarana yang dapat memfasilitasi lalu lintas pertukaran barang dan jasa tersebut. Peran teknologi sangat diperlukan agar transaksi dapat dilakukan secara efisien tanpa harus mengeluarkan biaya yang besar. Perkembangan teknologi ini menghasilkan suatu sistem penjualan yang dilakukan dalam jaringan (daring) atau sering disebut e-commerce.(Marta, 2017)

Bank Indonesia sebagai bank central telah mengumumkan Gerakan Nasional Non Tunai atau biasa yang disebut dengan GNNT, kegiatan tersebut memiliki tujuan untuk menguatkan pemahaman masyarakat tentang pentingnya menggunakan transaksi non tunai, maka sedikit demi sedikit mulailah terbentuk suatu organisasi, komunitas atau masyarakat yang lebih menggunakan instrumen non tunai (Less Cash Society/LCS) khususnya dalam melakukan transaksi atas kegiatan ekonominya. Bank Indonesia saat ini telah mengagendakan akan meningkatkan kualitas elektronik sebagai alat transaksi pembayaran non tunai dan meningkatkan kualitas prasarana dalam melakukan kegiatan ekonomi dalam bertransaksi, dalam peran serta ini memiliki tujuan menganjurkan mengganti tradisi membayar menggunakan tunai beralih menggunakan pembayaran non tunai. Diawali membiasakan menggunakan internet banking, ATM, kartu kredit atau debit maupung uang elektronik lainnya (Bank.(Indonesia, 2014)

Kartu kredit, kartu ATM/debet, dan uang elektronik (e-money) merupakan alat pembayaran non tunai yang paling sering digunakan masyarakat. Fungsi dari alat pembayaran tersebut sama dengan uang tunai dan meskipun sumber dana untuk ketiga alat pembayaran tersebut berbeda, tetapi tujuan dari penggunaannya sama, yaitu untuk berbelanja, mengirim uang, membayar berbagai tagihan, dan lain-lain. Alat pembayaran non tunai ini sangat memudahkan masyarakat dalam bertransaksi sehingga perputaran uang menjadi sangat cepat. Hal ini dapat dilihat dari pertumbuhan nilai transaksi dari kartu debet/ATM, kartu kredit, dan e-money yang cenderung menigkat dari tahun ke tahun pada tabel berikut ini:

Tabel 1. Nilai Transaksi Non Tunai Menggunakan Kartu Debet/ATM, Kartu Kredit dan E-Money Periode 2014-2018

\begin{tabular}{cccc}
\hline Tahun & $\begin{array}{c}\text { Kartu } \\
\text { Debet/ATM }\end{array}$ & $\begin{array}{c}\text { Kartu } \\
\text { Kredit }\end{array}$ & E-Money \\
\hline 2014 & $4,445,073,435$ & $255,057,458$ & $400,439,154$ \\
\hline 2015 & $4,897,794,438$ & $280,543,930$ & $535,579,528$ \\
\hline 2016 & $5,623,912,644$ & $281,020,518$ & $619,249,760$ \\
\hline 2017 & $6,200,437,636$ & $297,761,229$ & $943,319,933$ \\
\hline 2018 & $6,955,134,163$ & $314,294,068$ & $2,922,698,905$ \\
\hline
\end{tabular}


Sumber: Bank Indonesia (data diolah, 2019)

Berdasarkan tabel 1 dapat dilihat bahwa data penggunaan e-money lebih besar dibandingkan kartu kredit, padahal kartu kredit lebih dulu muncul dibandingkan e-money. Hal ini terjadi karena munculnya kebijakan baru dari pemerintah berupa kewajiban pembayaran tol menggunakan kartu atau e-money. Sehingga penggunaan e-money jauh lebih berkembang dibandingkan kartu kredit, meskipun e-money belum begitu lama muncul.

Peran sistem pembayaran non tunai akan berdampak semakin besar terhadap perekonomian suatu negara. Khususnya dengan semakin dominannya peran sistem pembayaran bernilai besar dibandingkan dengan bernilai kecil. Selain berdampak langsung terhadap masyarakat yang menggunakan, efisiensi dan kemudahan sistem pembayaran non tunai juga mendukung sistem keuangan nasional keseluruhan. Laju pertumbuhan ekonomi Indonesia periode 2014-2018 dapat dilihat pada gambar berikut:

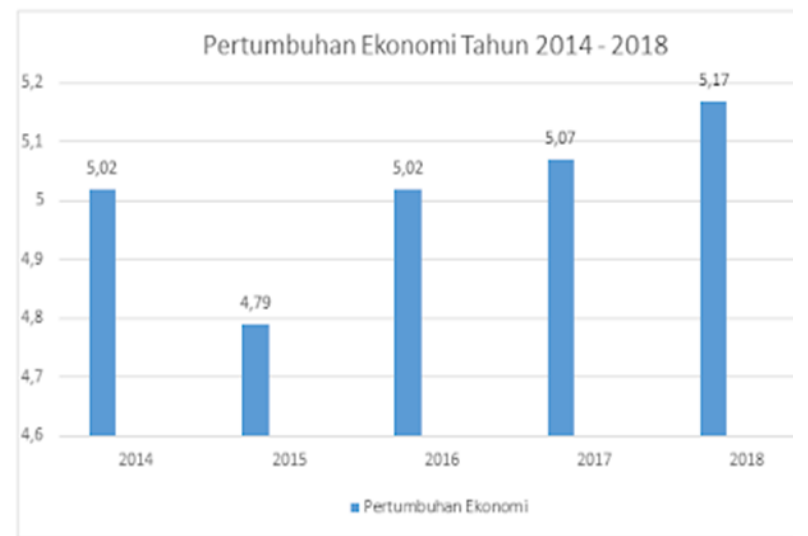

Sumber: Badan Pusat Statistik (2019)

Gambar 1. Pertumbuhan Ekonomi Indonesia Periode 2014-2018

Dari data diatas dapat dilihat bahwa pertumbuhan ekonomi Indonesia dari tahun 2014-2018 mengalami keadaan yang fluktuatif. Pada tahun 2014 sebesar 5,02\% kemudian mengalami penurunan di tahun 2015 menjadi 4,79\%. Pada tahun 2016 hingga 2018 mengalami peningkatan sebesar $5,02 \%$ kemudian naik menjadi $5,07 \%$ dan mengalami peningkatan yang cukup tinggi dibandingkan tahun sebelumnya pada tahun 2018 sebesar $5,17 \%$. Padahal pada tahun yang sama pembayaran non tunai mengalami kenaikan terus menerus tiap tahunnya. Namun realita yang terjadi perkembangan sistem pembayaran non tunai tidak didampingi dengan kenaikan pertumbuhan ekonomi di Indonesia.

Penelitian ini pada prinsipnya adalah untuk dapat melihat pengaruh alat pembayaran non tunai terhadap pertumbuhan ekonomi di Indonesia pada periode terbaru. Penelitian di fokuskan pada variabel transaksi non tunai meliputi data penggunaan kartu debit/ATM. kartu kredit dan e-money. untuk mengetahui pengaruhnya terhadap pertumbuhan ekonomi di Indonesia dengan indikator nilai Produk Domestik Bruto (PDB) pada periode tahun 2014-2018.

\section{Rumusan Masalah}

Rumusan masalah dalam penelitian ini memfokuskan pada pembahasan mengenai pengaruh alat pembayaran non tunai terhadap pertumbuhan ekonomi di Indonesia.

\section{Tujuan Penelitian}

Tujuan penelitian ini adalah untuk mengetahui bagaimana pengaruh alat pembayaran non tunai terhadap pertumbuhan ekonomi di Indonesia.

\section{Landasan Teori}

\section{Nilai Transaksi}

Nilai transaksi diatur pada Agreement on Implementation of Article VII of GATT dan telah tercantum pada pasal 15 UndangUndang Kepabeanan, yaitu nilai yang benar-benar dibayar oleh pembeli kepada penjual dan biaya-biaya lainnya yang 
dikeluarkan pembeli. Penambahan atas biaya-biaya yang dikeluarkan pembeli di luar harga yang disepakati harus menggunakan data yang obyektif dan terukur.

Menurut (Jafar, 2014) Nilai transaksi adalah total pembayaran yang sebenarnya dibayar atas barang dan jasa yang telah dilakukan baik yang sudah dibayar ataupun yang akan dibayar oleh pembeli kepada penjual atau untuk kepentingan penjual.

Dari pengertian diatas dapat disimpulkan bahwa nilai transaksi dalam sistem pembayaran merupakan nomial sesungguhnya yang telah dilakukan dalam proses pembayaran untuk pemenuhan kebutuhan masyarakat

\section{Alat Pembayaran Non Tunai}

Alat pembayaran non tunai sudah berkembang dan semakin lazim dipakai masyarakat. Kenyataan ini memperlihatkan bahwa jasa pembayaran non tunai yang dilakukan bank maupun lembaga selain bank (LSB), baik dalam proses pengiriman dana, penyelenggara kliring maupun sistem penyelesaian akhir (settlement) sudah tersedia dan dapat berlangsung di Indonesia. Saat ini cukup banyak variasi intrumen pembayaran non tunai, beberapa contoh yang cukup marak digunakan antara lain, Kartu ATM/debet, kartu kredit, dan uang elektronik (e-money).

Pembayaran non tunai dalam penggunaannya melibatkan jasa perbankan. Perbankan selaku badan usaha penghimpun dana masyarakat selayaknya memberikan pelayanan lalu lintas pembayaran yang dapat membanatu dalam pemenuan kebutuhan ekonomi nasabah. Jasa perbankan yang ditawarkan terdiri dari instrumen seperti cek, bilyet giro, nota debet, dan nota kredit, serta instrumen berbasis bukan warkat, seperti kartu ATM, kartu debet, dan kartu kredit (Mulyati, 2003)

Perkembangan sistem pembayaran ini didukung dengan adanya alat pembayaran dengan menggunakan kartu (APMK). Yang termasuk dalam APMK adalah aktivitas yang dalam proses pembayaran menggunakan kartu seperti, kartu ATM/debet dan kartu kredit. Transaksi pembayaran dengan menggunakan instrument APMK saat ini bersifat account based, sehingga setelmen transaksi dilakukan pada level bank dengan metode yang dipilih oleh masing-masing bank sesuai denga skala operasional jaringannya.(Lintangsari, 2018)

\section{Account Based Card (Kartu Debet/ATM)}

Account Based Card adalah alat pembayaran berbasis kartu dengan dana berasal dari rekening nasabah. Jenis kartu yang masuk pada kategori Account Based Card adalah ATM, kartu debet dan perpaduan kartu ATM dengen debet. Perkembangan Account Based Card dimulai dengan banyaknya penggunanan kartu ATM di masyarakat yang memudahkan masyarakat dalam bertransaksi ekonomi pembayaran (Mulyati, 2003).

Menurut Peraturan Bank Indonesia No.11/11/PBI/2009 tentang penyelenggaran kegiatan APMK (Alat Pembayaran dengan Menggunakan Kartu). Kartu ATM adalah APMK yang dapat digunakan untuk melakukan penarikan tunai dan/atau pemindahan dana dimana kewajiban pemegang kartu dipenuhi seketika dengan mengurangi secara langsung simpanan pemegang kartu pada Bank atau Lembaga Selain Bank (LSB) yang berwenang untuk menghimpun dana sesuai ketentuan perundang-undangan yang berlaku.

Kartu Debet adalah APMK yang dapat digunakan untuk melakukan pembayaran atas kewajiban yang timbul dari suatu kegiatan ekonomi, termasuk transaksi pembelanjaan, dimana kewajiban pemegang kartu dipenuhi seketika dengan mengurangi secara langsung simpanan pemegang kartu pada Bank atau Lembaga Selain Bank (LSB) yang berwenang untuk menghimpun dana sesuai ketentuan perundang-undangan yang berlaku. 


\section{Kartu Kerdit}

Kartu kredit merupakan alat pembayaran pengganti uang tunai yang dapat digunakan oleh konsumen untuk ditukarkan dengan barang dan jasa yang diinginkannya di tempat-tempat yang dapat menerima pembayaran dengan menggunakan kartu kredit (merchant).

Menurut Peraturan Bank Indonesia No.11/11/PBI/2009 tentang penyelenggaran kegiatan APMK (Alat Pembayaran dengan Menggunakan Kartu). Kartu Kredit adalah APMK yang dapat digunakan untuk melakukan pembayaran atas kewajiban yang timbul dari suatu kegiatan ekonomi, termasuk transaksi pembelanjaan dan/atau untuk melakukan penarikan tunai, dimana kewajiban pembayaran pemegang kartu dipenuhi terlebih dahulu oleh acquirer atau penerbit, dan pemegang kartu berkewajiban untuk melakukan pembayaran pada waktu yang disepakati baik dengan pelunasan secara sekaligus (charge card) ataupun dengan pembayaran secara angsuran.

Kartu Kredit adalah kartu yang umumnya dibuat dari bahan plastik dengan dibubuhkan identitas dari pemegang dan penerbitnya, yang memberikan hak terhadap siapa kartu kredit diisukan untuk menandatangani tanda pelunasan pembayaran harga dari jasa atau barang yang dibeli di tempat-tempat tertentu, seperti toko, hotel, restoran, penjualan tiket, pengangkutan dan lain-lain. Selanjutnya membebankan kewajiban kepada penerbit kartu kredit untuk melunasi harga barang dan jasa. Kemudian kepada penerbitnya diberikan hak untuk menagih kembali pelunasan harga tersebut dari pihak pemegang kartu kredit plus biaya-biaya lainnya, seperti bunga, biaya tahunan, uang pangkal, dengan dan sebagainya (Fuady, 2014)

Dari pengertian diatas dapat disimpulkan bahwa kartu kredit adalah alat pembayaran untuk membeli barang atau jasa di tempat-tempat yang sudah ditentukan, dan berupa kartu plastik. Pembiayaan dalam kartu kredit didahului dengan adanya perjanjian yang menawarkan cicilan kepada penggunanya untuk melunasi barang atau jasa konsumennya dalam jangka waktu tertentu.

\section{Electronic Money (Uang Elektronik)}

Penggunaan uang elektronik atau $e$ money yang inovatif dan praktis yang merupakan salah satu instrumen pembayaran non tunai dapat digunakan sebagai alternatif yang dapat menjangkau masyarakat yang selama ini belum mempunyai akses kepada sistem perbankan.

Menurut pasal 1 ayat (3) Peraturan Bank Indonesia Nomor 16/8/PBI/2014 tentang perubahan atas Peraturan Bank Indonesia Nomor 11/12/PBI/2009 tentang Uang Elektronik, bahwa yang dimaksud dengan uang elektronik (electronic money) adalah alat pembayaran yang memenuhi unsurunsur sebagai berikut:

a. Diterbitkan atas dasar nilai uang yang disetor terlebih dahulu kepada penerbit;

b. Nilai uang disimpan secara elektronik dalam suatu media server atau chip;

c. Digunakan sebagai alat pembayaran kepada pedagang yang bukan merupakan penerbit uang elektronik tersebut; dan

d. Nilai uang elektronik yang dikelola oleh penerbit bukan merupakan simpanan sebagaimana dimaksud dalam undangundang yang mengatur mengenai perbankan.

Sedangkan menurut (Rivai, Veithzal, 2007) menjelaskan bahwa yang dimaksud dengan Uang elektronik adalah alat pembayaran elektronik yang diperoleh dengan menyetorkan terlebih dahulu sejumlah uang kepada penerbit, baik secara langsung, maupun melalui agen-agen penerbit, atau dengan pendebitan rekening di bank, dan nilai uang tersebut dimasukan menjadi nilai uang dalam media uang elektronik, yang dinyatakan dalam satuan rupiah, yang digunakan untuk melakukan transaksi pembayaran dengan cara 
mengurangi secara langsung nilai uang pada media uang elektronik tersebut.

Dari pengertian diatas dapat disimpulkan bahwa uang elektronik adalah alat pembayaran dalam bentuk elektronik dimana nilai uangnya disimpan dalam media elektronik tertentu dapat berupa chip atau server. yang tujuannya agar membuat transaksi lebik mudah, praktis dan aman.

\section{Pertumbuhan Ekonomi}

Pertumbuhan ekonomi merupakan proses perubahan kondisi ekonomi suatu negara secara berkesinambungan menuju keadaan yang lebih baik selama periode tertentu. Pertumbuhan ekonomi diartikan sebagai perkembangan kegiatan dalam perekonomian yang menyebabkan barang dan jasa yang diproduksi dalam masyarakat bertambah dan kemakmuran masyarakat meningkat. Dengan kata lain pertumbuhan ekonomi mengukur prestasi dari perkembangan suatu perekonomian dari suatu periode ke periode lainnya (Sadono, 2015)

Sedangkan menurut (Arsyad, 2010) Pertumbuhan ekonomi diartikan sebagai kenaikan PDB atau PNB tanpa memandang apakah kenaikan itu lebih besar atau lebih kecil dari tingkat pertumbuhan penduduk, dan apakah terjadi perubahan struktur ekonomi atau perbaikan sistem kelembagaan atau tidak.

Pertumbuhan ekonomi secara umum di defenisikan sebagai peningkatan kemampuan dari suatu perekonomian dalam memproduksi barang-barang dan jasa-jasa. Pertumbuhan ekonomi adalah salah satu indikator yang amat penting dalam melakukan analisis tentang pembangunan ekonomi yang terjadi pada suatu negara. Pertumbuhan ekonomi menunjukkan sejauh mana aktivitas perekonomian akan menghasilkan tambahan pendapatan masyarakat pada suatu periode tertentu. Karena pada dasarya aktivitas perekonomian adalah suatu proses penggunaan faktor-faktor produksi untuk menghasilkan output, maka proses ini pada gilirannya akan menghasilkan suatu aliran balas jasa terhadap faktor produksi yang dimiliki oIeh masyarakat (Basri, 2010)

Berdasarkan beberapa uraian di atas, dapat disimpulkan bahwa pertumbuhan ekonomi merupakan perkembangan kegiatan dalam perekonomian yang tercermin dari kenaikan Produk Domestik Bruto (PDB) atau Produk Nasional Bruto (PNB) dalam jangka panjang tanpa memandang besar atau kecilnya pertumbuhan penduduk dan perubahan struktur ekonomi.

\section{Metode Penelitian}

Dalam penelitian ini, jenis penelitian yang digunakan adalah jenis penelitian deskriptif dengan pendekatan kuantitatif. Data sekunder yang digunakan adalah laporan bulanan nilai transaksi kartu debet/ATM, kartu kredit, dan e-money yang diterbitkan oleh Bank Indonesia (BI) dan nilai Produk Domestik Bruto (PDB) yang diterbitkan oleh Badan Pusat Statistik (BPS) pada periode tahun 2014-2018

Teknik analisis data yang dilakukan dalam penelitian ini adalah analisis regresi berganda dengan langkah awal dilakukan pengujian asumsi klasik yang terdiri dari uji normalitas, uji multikolinearitas, uji autokorelasi dan uji heteroskedatisitas untuk memastikan apakah model regresi yang digunakan tidak terdapat masalah multikolinearitas, autokolerasi, heteroskedastisitas dan data yang dihasilkan terdistribusi normal. Setelah memenuhi uji asumsi klasik dilakukan uji signifikansi simultan, uji signifikansi parsial, dan uji koefisien determinan. Adapun persamaan regresi linear berganda yang digunakan adalah sebagai berikut:

$\mathrm{Y}=\beta 0+\beta 1 \mathrm{X} 1+\beta 2 \mathrm{X} 2+\beta 3 \mathrm{X} 3+\mathrm{e}$

Dimana :

Y : Pertumbuhan Ekonomi

B0 : Konstanta 
$\beta 1 \ldots \beta 3$ : Koefisien masing masing variabel independen

X1 : Nilai transaksi kartu debet/ATM

$\mathrm{X} 2 \quad$ : Nilai transaksi kartu kredit

X3 : Nilai transaksi e-money

e : Standard Error

\section{Hasil dan Pembahasan}

\section{A. Uji Normalitas}

Uji normalitas digunakan sebagai langkah awal untuk mengetahui dalam model regresi penelitian apakah terdapat variabel pengganggu atau residual yang memiliki distribusi normal atau tidak. Uji normalitas dapat dilakukan dengan menggunakan metode grafik Normal Probability Plot atau dengan metode One Sample Kolmogrof-Smirnov. Hasil uji normalitas data pada penelitian ini dilihat sebagai berikut:

Tabel 2 Uji Normalitas

\begin{tabular}{lrr}
\hline \multicolumn{3}{c}{ One-Sample Kolmogorov-Smirnov Test } \\
\hline & & $\begin{array}{c}\text { Unstandardized } \\
\text { Residual }\end{array}$ \\
\hline $\mathrm{N}$ & Mean & 60 \\
Normal & Std. Deviation & 0 \\
Parameters & Absolute & $1.76 \mathrm{E}+04$ \\
Most & Positive & 0.069 \\
Extreme & Negative & 0.057 \\
Differences & -0.069 \\
& Kolmogorov-Smirnov Z & 0.536 \\
Asymp. Sig. (2-tailed) & 0.936 \\
\hline a. Test distribution is Normal. & \\
b. Calculated from data. &
\end{tabular}

Sumber: Hasil Olah Data Statistik, 2019

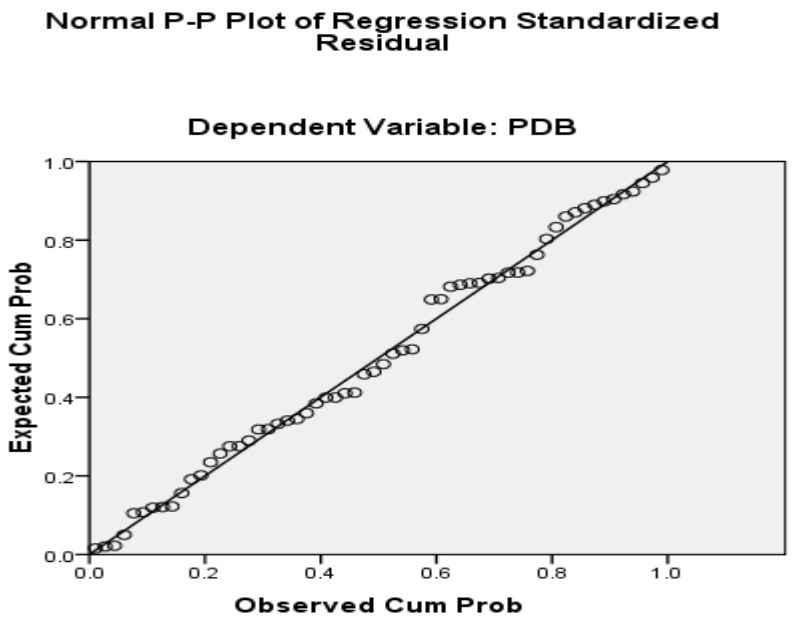

Sumber: Hasil Olah Statistik, 2019

Gambar 2. Diagram Plot Normalitas Data

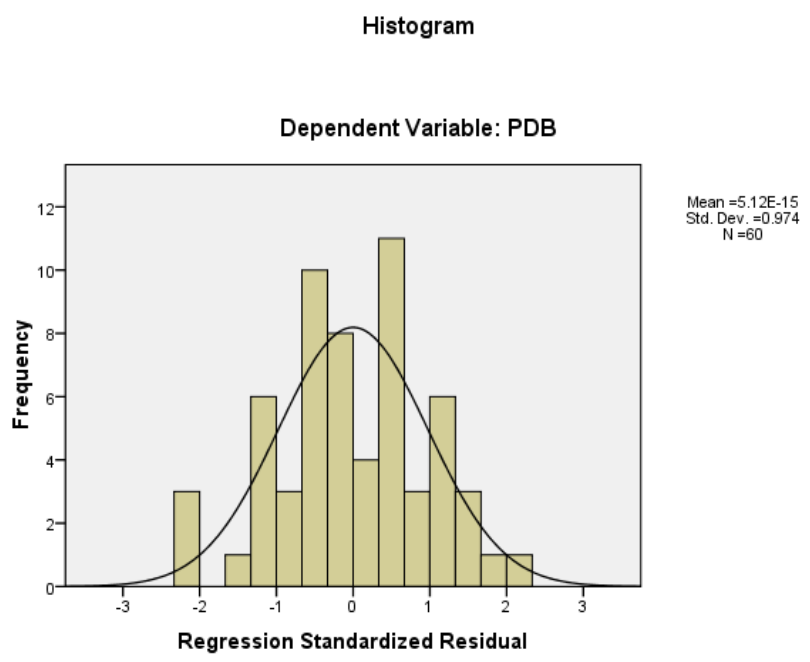

Sumber: Hasil Olah Statistik, 2019

Gambar 3. Grafik Histogram

Berdasarkan hasil uji normalitas pada tabel 2 dengan menggunakan uji Kolmogrov-Smirnov menujukkan hasil sebesar 0,936 yang berarti bahwa seluruh variabel memiliki nilai asymp. Sig (2tailed) diatas 0,05 . Sedangakan berdasarkan uji normalitas pada gambar 1 dan 2 dengan menggunakan grafik dapat dilihat bahwa titik-titik menyebar disekitar garis diagonal atau mengikuti arah garis diagonal. Dengan demikian dapat disimpulkan bahwa semua 
variabel telah terdistribusi normal dan model regresi layak digunakan.

\section{B. Uji Multikolinearitas}

Tabel 3. Uji Multikolinearitas

\begin{tabular}{ccc} 
Variabel & Tolerence & VIP \\
\hline Kartu Debit/ATM & 0.207 & 6.361 \\
\hline Kartu Kredit & 0.248 & 4.035 \\
\hline E-Money & 0.345 & 2.911 \\
\hline
\end{tabular}

Sumber: Hasil Olah Statistik, 2019

Hasil uji melalui Variance Inflation Factor (VIP) pada hasil output SPSS tabel Coefficients, seluruh variabel menujukkan nilai tolerance $>0,1$ dan VIF $<10$, maka dapat dinyatakan model regresi linier berganda terbebas dari multikolinearitas dan dapat digunakan dalam penelitian.

\section{Uji Autokorelasi}

Tabel 4. Uji Autokorelasi

$\frac{\text { Durbin-Watson }}{1.521}$

\section{Sumber: Hasil Olah Statistik, 2017}

Dari hasil output SPSS didapatkan nilai Durbin-Watson untuk model regresi Return On Assets (ROA) sebagai variabel dependen senilai 1,851. Hasil nilai DurbinWatson hitung terletak diantara batas atas (du) dan batas bawah (4-du) atau du $<\mathrm{dw}<$ 4-du yaitu $1,480<1,521<2,311$ sehingga keputusan yang diambil adalah tidak adanya autokorelasi negatif dan positif atau dengan kata lain tidak ada autokorelasi dalam model regresi ini. Dengan demikian dapat dikatakan bahwa model terbebas dari autokorelasi.

\section{Uji Heteroskedastisitas}

Pengujian heteroskedastisitas digunakan untuk melihat apakah dalam model regresi terjadi ketidaksamaan dari pengamatan satu kepengamatan lainnya. Model regresi dalam penelitian dikatakan baik apabila terhindar atau terbebas dari heteroskedastisitas.

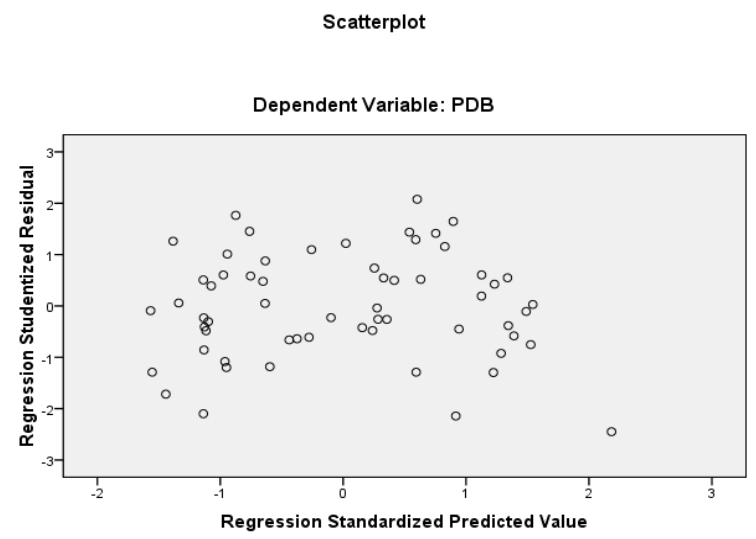

Sumber: Hasil Olah Statistik, 2019

Gambar 4 Grafik Scattterplot

Dari grafik scatterplot terlihat bahwa titik-titik menyebar secara acak serta tersebar baik diatas maupun dibawah angka 0 pada sumbu $\mathrm{Y}$ dengan demikian dapat disimpulkan bahwa model regresi ini tidak terjadi heteroskedastisitas.

\section{E. Analisis Regresi Linier Berganda}

Hasil perhitungan Regresi Linier Berganda dapat dilihat pada tabel berikut:

Tabel 5. Hasil Regresi Berganda

\begin{tabular}{cccc}
\hline \multirow{2}{*}{ Model } & \multicolumn{2}{c}{$\begin{array}{c}\text { Unstandardized } \\
\text { Coefficients }\end{array}$} & $\begin{array}{c}\text { Standardized } \\
\text { Coefficients }\end{array}$ \\
\cline { 2 - 4 } & B & $\begin{array}{c}\text { Std. } \\
\text { Error }\end{array}$ & Beta \\
\hline $1 \quad$ (Constant) & 26.179 & 3.485 & \\
\hline $\begin{array}{l}\text { Kartu_Debit_ } \\
\text { ATM }\end{array}$ & 0.071 & .019 & 0.282 \\
\hline Kartu_Kredit & 0.047 & .012 & 0.393 \\
\hline & 0.084 & .023 & 0.621 \\
\hline E_Money & &
\end{tabular}

Sumber: Hasil Olah Statistik, 2019 
Berdasarkan hasil pada tabel 5 diperoleh persamaan regresi sebagai berikut:

$Y=26,179+0,071 X_{1}+0,047 X_{2}+0,084$

$\mathrm{X}_{3}+\varepsilon$

Intrepretasi dari persamaan regresi linier berganda tersebut adalah:

Nilai konstanta (a) sebesar 26,179. Hal ini menunjukkan bahwa jika variabel independen Kartu Debit/ATM, Kartu Kredit dan E-Money diasumsikan dalam keadaan tetap, maka variabel dependen PDB akan naik sebesar 26,179.

Nilai koefisien regresi Kartu Debit/ATM bernilai positif yaitu sebesar 0,071 yang berarti jika variabel Kartu Debit/ATM naik sebesar 1 satuan dengan asumsi variabel independen lain nilainya tetap, maka PDB akan naik sebesar 0,071 satuannya.

Nilai koefisien regresi Kartu Kredit bernilai positif yaitu sebesar 0,047 yang berarti jika variabel Kartu Kredit naik sebesar 1 satuan dengan asumsi variabel independen lain nilainya tetap, maka PDB akan naik sebesar 0,047 satuannya.

Nilai koefisien regresi E-Money bernilai positif yaitu sebesar 0,084 yang berarti jika variabel E-Money naik sebesar 1 satuan dengan asumsi variabel independen lain nilainya tetap, maka PDB akan naik sebesar 0,084 satuannya.

\section{F. Analisa Koefisien Determinasi}

Koefisien Determinasi (R2) digunakan untuk mendeteksi kemampuan model dalam menjelaskan variabel dependen. Nilai koefisien determinasi antara nol dan satu. Semakin mendekati satu nilai R2 menjelaskan bahwa variabel-variabel independen memberikan semua informasi yang dibutuhkan untuk memprediksi variabel dependen. Hasil perhitungan Koefisien Determinasi dapat dilihat pada tabel berikut:
Tabel 6. Koefisien Determinasi

\begin{tabular}{ccccc}
\hline \multicolumn{4}{c}{ Model Summary $^{\mathbf{b}}$} \\
\hline Model & $\mathrm{R}$ & $\begin{array}{c}\mathrm{R} \\
\text { Square }\end{array}$ & $\begin{array}{c}\text { Adjusted } \\
\text { R Square }\end{array}$ & $\begin{array}{c}\text { Std. } \\
\text { Error of } \\
\text { the } \\
\text { Estimate }\end{array}$ \\
\hline 1 & $0.944^{\mathrm{a}}$ & 0.891 & 0.886 & 1,81048 \\
\hline $\begin{array}{l}\text { a. Predictors: (Constant), Kartu_Debit_ATM, } \\
\text { Kartu_Kredit, E_Money } \\
\text { b. Dependent Variable: PDB }\end{array}$
\end{tabular}

Sumber: Hasil Olah Statistik, 2019

Berdasarkan hasil pada tabel 6 pengujian koefisien determinasi (Adjusted $\mathrm{R}^{2}$ ) PDB diperoleh nilai sebesar 0,891 . Dengan kata lain hal ini menunjukkan bahwa besar presentase variasi PDB yang bisa dijelaskan oleh variasi dari ketiga variabel bebas yaitu Kartu Debit/ATM, Kartu Kredit dan EMoney sebesar $89,1 \%$, sedangkan sisanya sebesar $10,9 \%$ dijelaskan oleh sebab-sebab lain diluar model.

\section{G. Hasil Uji F}

Uji F (Simultan) dilakukan untuk mengetahui pengaruh nyata secara statistik diantara variabel-variabel bebas seperti kartu debet/ATM, kartu kredit dan e-money secara bersama-sama terhadap variabel terikat yaitu PDB. Uji F dapat diketahui dengan membandingkan nilai sig. dengan tingkat signifikansi $5 \%(\alpha=0,05)$. Hasil perhitungan uji $\mathrm{F}$ dapat dilihat pada tabel berikut:

Tabel 7. Hasil Uji F

\begin{tabular}{|c|c|c|c|c|c|c|}
\hline \multicolumn{7}{|c|}{ ANOVA $^{b}$} \\
\hline & Model & $\begin{array}{l}\text { Sum of } \\
\text { Squares }\end{array}$ & df & $\begin{array}{l}\text { Mean } \\
\text { Square }\end{array}$ & $\mathrm{F}$ & Sig. \\
\hline \multirow{3}{*}{1} & Regression & 1.506 & 3 & 5.019 & 153.127 & $.000^{\mathrm{a}}$ \\
\hline & Residual & 1.836 & 56 & 3.278 & & \\
\hline & Total & 1.689 & 59 & & & \\
\hline \multicolumn{7}{|c|}{$\begin{array}{l}\text { a. Predictors: (Constant), Kartu_Debit_ATM, } \\
\text { Kartu_Kredit, E_Money }\end{array}$} \\
\hline \multicolumn{7}{|c|}{ b. Dependent Variable: PDB } \\
\hline
\end{tabular}

Sumber: Hasil Olah Statistik, 2019 
Berdasarkan hasil output pada tabel 7 menunjukkan bahwa F-hitung (FStatitstik) sebesar 153,127 sedangkan F-tabel dengan df $2(n-k-1)=56$ adalah 3,161 dengan demikian F-Hitung > F-Tabel $(153,127>$ $3,161)$ pada tingakt signifikansi $<0,05$ $(0,000<0,05)$ artinya semua variabel independen secara bersama-sama berpengaruh signifikan terhadap variabel dependen.

\section{H. Hasil Uji t}

Pengujian ini dilakukan untuk mengetahui apakah terdapat pengaruh dari masing-masing variabel bebas terhadap variabel terikat. Uji ini dapat dilakukan dengan melihat kolom signifikansi dengan membandingkan tingkat signifikansi 5\% $(\alpha$ $=0,05)$. Hasil uji $\mathrm{t}$ dapat diketahui melalui tabel berikut ini:

Tabel 8. Hasil Uji t

Coefficients $^{\mathrm{a}}$

\begin{tabular}{llll}
\hline & & & \\
& & & \\
& & & \\
& & & \\
\hline 1 & (Constant) & 17.843 & 0.000 \\
\hline & Kartu_Debet_ATM & 11.544 & 0.000 \\
\hline & Kartu_Kredit & 23.311 & 0.002 \\
\hline & E_Money & 21.613 & 0.012 \\
\hline
\end{tabular}

a. Dependent Variable: PDB

Sumber: Hasil Olah Statistik, 2019

Hasil perhitungan dalam tabel coefficients diatas dapat diuraikan sebagai berikut;

1. Hasil pengujian menunjukkan nilai koefisien sesuai dengan hipotesa yang diajukan dalam penelitian ini dimana diduga terdapat pengaruh positif variabel kartu debet/atm terhadap pertumbuhan ekonomi. Hasil nilai p-value sebesar $0,000<0,05$ (alpha 5\%), maka $\mathrm{Ha}$ diterima dan disimpulkan secara statistik pada tingkat kepercayaan $95 \%$ terdapat pengaruh positif Kartu Debet/ATM terhadap pertumbuhan ekonomi. Hasil penelitain ini sesuai dengan penelitian Nirmala (2011) dan Lintangsari, dkk (2018)yang menyatakan bahwa kartu debet/atm berpengaruh positif terhadap pertumbuhan ekonomi

2. Hasil pengujian menunjukkan nilai koefisien sesuai dengan hipotesa yang diajukan dalam penelitian ini dimana diduga terdapat pengaruh positif variabel kartu kredit terhadap pertumbuhan ekonomi.Hasil nilai p-value sebesar $0,002<0,05$ (alpha 5\%), maka Ha diterima dan disimpulkan secara statistik pada tingkat kepercayaan $95 \%$ terdapat pengaruh positif kartu kredit terhadap pertumbuhan ekonomi. Hasil penelitain ini sesuai dengan penelitian Nirmala (2011) dan Lestari (2017) yang menyatakan bahwa kartu kredit berpengaruh positif terhadap pertumbuhan ekonomi

3. Hasil pengujian menunjukkan nilai koefisien sesuai dengan hipotesa yang diajukan dalam penelitian ini dimana diduga terdapat pengaruh positif variabel e-money terhadap pertumbuhan ekonomi.Hasil nilai p-value sebesar $0,012<0,05$ (alpha 5\%), maka Ha diterima dan disimpulkan secara statistik pada tingkat kepercayaan $95 \%$ terdapat pengaruh positif Kartu Debet/ATM terhadap PDB. Hasil penelitain ini sesuai dengan penelitian Ritonga (2018) dan Lintangsari (2018) yang menyatakan bahwa e-money berpengaruh positif terhadap pertumbuhan ekonomi

\section{Kesimpulan}

Dari hasil penelitian ini disimpulkan bahwa transaksi non tunai seperti penggunaan kartu debet/atm, kartu kredit dan e-money secara positif dan signifikan mempengaruhi pertumbuhan ekonomi Indonesia. Pengaruh 
ini dibuktikan baik secara parsial maupun secara simultan.

Pertumbuhan ekonomi merupakan salah satu efek positif dari penggunaan kartu sebagai alat transaksi yang tentunya berkaitan erat dengan benefit yang ditawarkan pembayaran elektronik, seperti aspek keamanan, kemudahan, kenyamanan dalam bertransaksi tanpa uang tunai, peningkatan efisiensi serta mendukung sistem keuangan nasional keseluruhan, sehingga kondisi ini dapat meningkatkan konsumsi masyarakat.

Peningkatan penggunaan alat pembayaran non tunai dapat berdampak terhadap penurunan permintaan uang dimasyarakat. Secara teoritis, penurunan permintaan uang akan menyebabkan penurunan tingkat suku bunga di pasar uang karena masyarakat akan memilih menggunakan alat pembayaran non tunai yang dibarengi dengan menyimpan uang di bank yang bersangkutan. Hal ini membuat biaya pinjaman lebih kompetitif, sehingga meningkatkan investasi perusahaan, meningkatkan output riil nasional dan pertumbuhan ekonomi serta peningkatan kesejahteraan masyarakat.

\section{DAFTAR PUSTAKA}

Arsyad, L. (2010). Ekonomi Pembangunan. Yogyakarta: UPP STIM YKPN.

Badan Pusat Statistik. (2018). Produk Domestik Bruto Atas Dasar Harga Konstan Tahun Dasar 2010. http://www.bps.go.id

Bank Indonesia. (2012). Peraturan Bank Indonesia Nomor: 14/2/PBI/2012 tentang Perubahan atas PBI Nomor:11/11/PBI/2009 tentang Kegiatan Alat Pembayaran dengan Menggunakan Kartu

Bank Indonesia. (2018). Peraturan Bank Indonesia Nomor 20/6/PBI/2018 Tentang Penyelenggaraan Uang Elektronik (Electronic Money).
Bank Indonesia. (2019) Statistik Sistem Pembayaran- Menggunakan Kartu. http://www.bi.go.id

Basri, Faisal, Munandar, H. (2010). Lanskap Ekonomi Indonesia: Kajian dan Renungan Terhadap MasalahMasalah Struktural, Transformasi Baru, dan Prospek Perekonomian Indonesia. Jakarta: Prenada Media Group.

Fuady, M. (2014). Hukum Tentang Pembiayaan. Bandung: PT. Citra Aditya Bakti.

Ghazali, I. (2016). Aplikasi analisis multivariate dengan program IBM SPSS 23. Semarang: Universitas Diponegoro.

Indonesia, B. (2014). Mencanangkan Gerakan Nasional Non Tunai. Jakatrta. Retrieved from https://www.bi.go.id/id/ruangmedia/siaranpers/pages/sp_165814.aspx

Jafar, M. (2014). Peenetapan Nilai Transaksi dengan Menggunaakan Rumus Tertentu, Tepatkah?. Retrieved August 15, 2019, from https://bppk.kemenkeu.go.id/id/publik asi/artikel/148-artikel-bea-dancukai/9144-penetapan-nilai-transaksidengan-menggunakan-rumus-tertentutepatkah

Lestari, P. R. (2017). Perkembangan Instrumen Pembayaran Non Tunai Dalam Menyumbang Pertumbuhan Ekonomi Di Indonesia. Jurnal Ilmiah Mahasiswa FEB Universitas Brawijaya, 5, No 2. Retrieved from https://jimfeb.ub.ac.id/index.php/jimfe b/article/view/3916

Marta, M. F. (2017). "Daya Beli Turun atau Orang Malas Belanja?”. Retrieved August 15, 2019, from https://ekonomi.kompas.com/read/201 7/09/20/060000026/daya-beli-turunatau-orang-malas-belanja-

Mulyati, S. T. S. (2003). Kebijakan Sistem Pembayaran di Indonesia. Jakarta: 
Pusat Pendidikan dan Studi Kebanksentralan (PPSK) BI.

N. Lintangsari, N. Hidayati, Y. Purnamasari, H. Carolina, and W. R. (2018). Analisis Pengaruh Instrumen Pembayaran Non-Tunai Terhadap Stabilitas Sistem Keuangan Di Indonesia. Jurnal Dinamika Ekonomi Pembangunan, 1 No 1, 447-462. https://doi.org/https://doi.org/10.14710 /jdep.1.1.47-62

Nirmala, Tiara, Widodo, T. (2011). Effect of Increasing Use the Card Payment Equipment on the Indonesian Economy. Jurnal Bisnis Dan Ekonomi $(J B E), 18$, No 1. Retrieved from https://www.unisbank.ac.id/ojs/index.p $\mathrm{hp} / \mathrm{fe} 3 /$ article/view/528

Ritonga, P. (2018). Pengaruh Pembayaran Non Tunai terhadap Pertumbuhan Ekonomi di Indonesia. Repositori Universitas Sumatera Utara.

Retrieved from
http://repositori.usu.ac.id/handle/1234 56789/2286

Rivai, Veithzal, A. P. V. dan F. N. I. (2007). Bank and Financial Institution Management. Jakarta: PT Raja Grafindo Persada.

Sadono, S. (2015). Ekonomi Pembangunan: Proses, Masalah dan Dasar Kebijakan. Jakarta: Prenada Media Group.

Sugiono. (2016). Metode Penelitian Kuantitatif, Kualitatif dan $R$ \& $D$. Bandung: Alfabeta. 